\title{
Young people - citizens in times of climate change? A childist approach to human responsibility
}

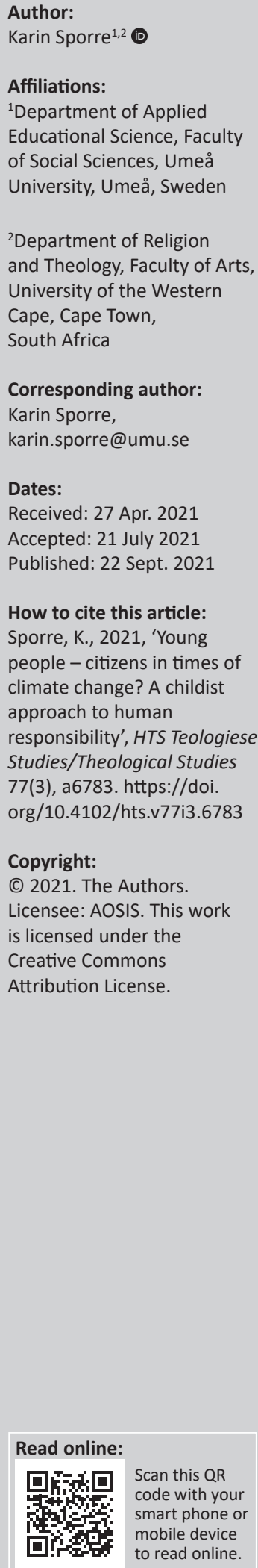

The matters of climate change are presently of concern existentially and ethically to the children and the youth. Worldwide school strikes in 2018-2019 and the Fridays for Future movement demonstrate how the young citizens assume socio-political responsibility. However, what possibilities do children and young people actually have to influence global discourse? Are adequate thought structures in place for them to be taken seriously in matters of concern to them? Given that children and youth engage with the issues of climate change, with a concern for their own future and that of our planet, the aim of this article was to take a child-centred ethical perspective and to theoretically explore conditions for intentional inclusion of children and their ethical concerns. In such a critical exploration, aspects of identity politics and intersectionality are reviewed. Empirical results from an interview study with children aged between 10 to 12 years are presented demonstrating that climate changes are of existential and ethical importance to them. Thereafter, a 'childist' perspective is introduced and discussed. The interviews were carried out during 2019 in eight schools in South Africa and Sweden. The children were individually interviewed with a method allowing for open responses. The schools in both countries were located in areas where a lack of water had been experienced. In this article, a theoretical framework is developed based on the ethical recognition of a commonly shared human responsibility and using the concept of 'empowered inclusion'. It recognises children in their own right and identifies vulnerability and interdependence as being foundational to human existence.

Contribution: In present times, as the concern for their own future, that of future generations and that of the planet is becoming an integral part of the identities of children and youth, both existentially and ethically, this article brings to this special issue a discussion of conditions for a child-centred view on human responsibility.

Keywords: citizenship of youth; identity politics; intersectionality; childism; human responsibility; climate change; Greta Thunberg.

\section{Introduction}

Matters of being able to influence in line with one's own interests and needs, that is, representation in a political sense, has a long history, most often one of struggle. In the South African case, the elections in 1994 represented a milestone as the struggles against racism finally resulted in the granting of enfranchisement to all above the age of 18. In Sweden, a western European country, a similar event took place in 1921 when women received voting rights and equal voting power was granted to all persons above 23 years irrespective of their economic resources and in 1975 the voting age became 18 years. However, what about those aged less than 18 years and their chances of having influence regarding their concerns, especially those related to climate change?

This article demonstrates through interviews with children how they assume ethical responsibility for such issues. Furthermore, it explores an ethical philosophical framework for including children on equal footing with grown-ups. Before approaching this, the article provides a background from some of the theoretical discussions on subjectivity in the struggle for the recognition of groups of 'others' whose rights as subjects was or is hindered by sexism, racism, economic exploitation etc. (cf. Braidotti 2013). In this article first we will briefly explore the movement in the current scenario amongst children and youth in relation to climate change, which will provide critical reflection over ethical issues and ethical theory of crucial and contemporary democratic relevance.

Note: Special Collection: New Landscapes in Identity: Theological, Ethical and Other Perspectives, sub-edited by John Klaasen (University of the Western Cape). 


\section{Concerns of children and youth}

One young person whose voice has reached seemingly far is the Swedish teenager Greta Thunberg. After having gone on a self-organised individual school strike for the climate, Thunberg received public attention and was asked between 2018 and 2019 to address, amongst others, the Swedish People's Climate March, the British Parliament, the EU Parliament, the World Economic Forum at Davos and the UN General Secretary (Kvamme 2019:9). Her speeches and actions have resulted in the global movement Fridays for Future (n.d.), a worldwide movement with a young leadership. In his study, Kvamme (2019:6-27) analysed 10 of Thunberg's speeches. The focus of his analysis was on environmental values, and Kvamme (2019:27) concluded that the value of future generations is crucial in her speeches when she transforms environmental values into cosmopolitan political claims. Kvamme (2019:6-27) also notes how Thunberg somewhat ambiguously addresses adults, sometimes as being responsible for the present situation and through that having let the children down, and other times being those with agency who are supposed to lead the way out of the crisis, thus resulting in 'us' designating children and 'you' referring to adults.

The concern for future generations visible in Thunberg's speeches points to the paradoxical situation of children and young people, who will live most of their lives experiencing the dangers of climate change that the world is facing now (ICCP 2021). They are the ones confronted with considerable difficulties getting their voices heard because of the existing understanding of citizenship and of who should have a voice in public. Wall (2011:86-100) presented an extensive overview of the possibilities for children and young people under 18 years of age, a third of all humanity, to express their political concerns and to be represented within democratic structures. When Wall (2011:88) critically reviewed various projects from a number of countries intending to facilitate children and youth in expressing their concerns, he noted that although such efforts might be intended to let children be heard 'children do not exercise power on their own behalf ...'. Also, although children can be citizens of a particular country (although this is not always the case for migrants), their citizenship does not in itself mean that they can exert any political influence. A crucial theoretical hindrance is their dependence on others because autonomy, a classic criterion for political rights, cannot be regarded as something they hold. Furthermore, their capacity to argue for themselves is limited. In contrast to these criteria, Wall argues that interdependence is a crucial condition for human existence. He also questions whether the possibility to raise one's voice and to argue one's case is an adequate criterion for political representation, especially from the point of view of children and young people (cf. other marginalised groups) who may not be so experienced in arguing their case. In addition, children ought not only to be understood as persons to be responded to from a grown-up world but also as political actors in themselves (Wall 2011:95). Their democratic representation based on their own concerns and questions demands new thought structures, and Wall argues that a rethinking is needed if they are not to remain marginalised in terms of political representation (Wall 2011:86-100).

\section{Theorising on marginal groups and politics of representation}

In her book Justice and the Politics of Difference (Young 1990), feminist political scientist Iris Marion Young brought the matter of marginalised groups and their political representation to the fore. Young discussed a politics of identity and formulated her theory of the 'five faces of oppression'. Thereby she pointed to how marginalised groups such as African Americans, gays and lesbians, indigenous peoples and women have had to struggle against societal oppression and domination because of racism, sexism, ethnic prejudice, economic exploitation and normative heterosexuality. A politics of identity could then be a response in struggles for social justice. However, Young (1990:156-191) pointed to the risk with the essentialising of group identities by those holding power whereby differences between human beings were reduced. Later, Young (1997:23-27) discussed the matter of essentialism by using the concept of 'seriality' (from French philosopher J.P. Sartre) when dealing with the matters of differences within a given political group. Young (1997:23-27) emphasised how amongst women it is rather similarities in their societal positioning that can make women, or rather some of them, form a political potential collective and not an identity, biology or any other attribute. In this way differences within what might become a political action group can be recognised, but not hinder the forming of a group around a common political concern.

Regarding women as a marginalised group and the new concept of political representation, 'intersectionality' came to the fore through the work of Crenshaw (1991). Discussing the vulnerable situation of African American women under conditions of racism, sexism and economic oppression, Crenshaw coined the concept of intersectionality. This created conditions for the naming and analysis of the threefold forms of oppression that African American women suffer. Through Crenshaw's work and the conceptualisation on intersectionality, African American women got a resource for a discussion that had been going on for some time. One African American ethicist, the womanist theologian Cannon $(1988,1995)$, was amongst those who also addressed the complex oppression that resulted in the silencing of the voices of African American women caused by the racism, sexism and classism they experienced. The use of the concept of intersectionality has proven to be academically productive in varying contexts, and little more than 20 years after the suggestion of the concept Cho, Crenshaw and McCall (2013) reviewed the development of the concept. They observed the various ways that academic discussions had taken the concept further, developed theories, applied them and created conditions for praxis through intersectionality studies.

Within childhood studies, and of relevance here, the concept of intersectionality has been used, for example, to link social structures and children's agency (Frödén \& Quennerstedt 
2020). In such a framework, age is understood as one possible category for intersecting with, for example, gender and sexuality, and this opens up possibilities to recognise diversity and differences between children - noting that children are not a homogenous group and that children are differently situated, that is, they live under different circumstances. However, the concept of age can also in itself be questioned in relation to childhood studies. Sundhall (2017:164-171) critically discussed age as a category through which adulthood is naturalised and becomes the hidden norm (cf. how masculinity or white supremacy becomes normalised in a sexist or racist binary) resulting in the subordination of children and leading to children and their ideas being left unrecognised and put aside. Sundhall's own work exemplified how this exclusion happens and as a contrast she argued for the inclusion of the views of children and youth in ways that come to question the normativity of adult-centred views.

\section{'Childism': A crucial concept}

To sustain her argument, Sundhall built on the work of Wall's (2010) Ethics in Light of Childhood and his way of understanding 'childism'. With a focus on human beings as one category (and not divided into children and adults), childism helped Sundhall to address children's experiences as something that can transform 'understandings and practices for all humans, not only for non-adults'. In addition, 'childism can then be an approach that challenges and changes structures and possibilities' (Sundhall 2017:165). When Wall himself (2011:86-100) in brief terms referred to this own earlier work (Wall 2010) he described childism in the following way: 'By this I mean ... a fundamental restructuring of fundamental social norms in response to children's experiences' (Wall 2011:87). The theoretical background to Wall's childism will be further explored in this article, but to be observed already here, Wall used 'childism' in the same way as other -isms such as 'feminism, womanism, environmentalism and queer theory and the like' (Wall 2011:87) function, namely to denote strivings by marginalised groups for political recognition.

\section{Aim of the article}

As indicated above, the situation of climate change has become an existential and ethical concern to children and youth concerned with their future, that of future generations and that of the planet Earth. Although children and young people can be citizens in a formal sense, adequate structures for democratic political representation of their views are lacking. Theories of citizenship, identity politics or intersectionality are not sufficient because of the adultcentred character of the paradigms. Therefore, the aim of this article is to explore and present the ideas of 'childism' as a possible ethical theoretical background to develop frameworks for recognition and inclusion of the views expressed by children and youth of today towards a more inclusive understanding of a shared human responsibility in relation to climate change. Thereby, the concerns of children and young people - their questions and their expressions of these questions - come to push for a renewed discussion of conditions for a common human responsibility.

To demonstrate the significance of the matters of climate change in the lifeworld of today's children, examples from an interview study with 41 South African and Swedish children are presented. 'Childism' as elaborated on by Wall (2010) is the ethical grounding for the child-centred approach to be discussed. Other texts by Wall $(2011,2019)$ and Josefsson and Wall (2020) are additional resources for the explorative discussion.

\section{Methodological considerations}

From a methodological point of view this article consists of two parts: (1) the use of empirical material from an interview study with children and (2) an exploratory theoretical discussion around 'childism'. The methodological issues related to the interview study will first be discussed and thereafter those related to the theoretical discussion.

During the first part of 2019, 41 South African and Swedish children aged 10-12 years were individually interviewed in a study focusing on children, sustainability and hope. Ethical permission to carry out the study was sought and given from relevant authorities in both countries. Parents or guardians of the children and the children themselves gave consent to participate in the study. The children came from four different schools in each country, and the schools were chosen in parts of the two countries where the inhabitants had experienced shortage of water. In Sweden this was because of the summer of 2018 being extremely dry with water restrictions being issued in certain areas. In South Africa, the situation was caused mainly by a few years of drought because of changing rain patterns. The children were interviewed via a method used earlier in Sweden and reported on in studies such as Hartman (1986) and Hartman and Torstensson-Ed (2007), and developed further for this study with more focus on sustainability. The method is based on open questions posed to the children; in this study a few of the questions used pictures and others were without pictures. For two questions, children were asked for written responses. The interviews lasted between 17-41 $\mathrm{min}$, with the majority of them lasting between 25-30 min. The interview guide that was used was quite strictly followed allowing for question-by-question comparison in the analysis. All children were interviewed in the medium of instruction at their school, English and Swedish, respectively. The individual interviews took place during school hours and the eight participating school classes were offered a visit by the researcher to the full class to introduce the study, of which seven classes accepted. Five children participated from each school class, except for one from which six participated. The interviews were transcribed verbatim in full by the researcher. In this article examples of answers are given from the start of the interview during which questions addressed the situation of shortage or lack of water and the children were asked about whether they had heard about water restrictions, if their families had done anything special to save water, and why it is important that we save water. 
Regarding the selection of schools, it can be mentioned that the school fees of the chosen South African schools vary considerably, meaning that children from various socioeconomic backgrounds took part. The chosen Swedish schools also represent a variety of socio-economic and educational background amongst the parents of the children, as possible to note from public statistics. In this way, a qualitative variation could be expected in the children's answers, but still the prime indicator for the choice of schools in the two countries was a shared experience of the children living in areas where scarcity of water had been experienced. However, the degree to which the situation of access to water affected daily life was very different in one of the South African areas at the time the study took place, as during the time in parts of that town numerous households were without water or water was not regularly distributed. Finally, and as already stated, the purpose of using a part of the results of this study in this article is to demonstrate the existential and ethical significance for children of issues related to climate change.

The next part of article deals with the exploration and discussion of a framework based in 'childism', and is primarily a study of texts exploring the main points of the ethical theory of Wall (2010) and its consequences for the recognition of the views of children and young people regarding climate change and leading to a discussion of human responsibility. The underlying concerns that drive this exploration and search for an adequate framework can be summarised as three main points: (1) the urgency of matters of climate change as communicated by youth and children, (2) the self-confidence and trust in themselves that some of the interviewed children demonstrate when bringing the ethical issues to the fore, thus exemplifying democratic action, but also in contrast showing the lack of trust in themselves and expressions of abandonment from adults and (3) the responsibility that the youth in Fridays for Future (n.d.) and the interviewed children put on themselves, which raises questions of how responsibility can be shared by the grown-up world. The framework this article seeks to explore and identify represents an effort to respond to this.

Based on these underlying concerns, the following questions guide the exploration and discussion of Wall's 'childist' approach:

- How can the existence of children as human beings be understood?

- What implications does this have for the recognition of the views of children and youth in terms of a changed understanding of theoretical democratic structures such as citizenship?

- What characterises a 'childist'-inspired view of shared human responsibility in relation to climate change?

The results of this article are consequently of two kinds: the establishment of the presence of existential and ethical concerns in the interview material of school children in South Africa and Sweden, and a tentative framework indicating directions for how the political engagement of children and youth can be interpreted and their self-assumed responsibility can be shared.

\section{Children's existential and ethical questions}

\section{Sweden: Water, a restricted resource}

As indicated, with the purpose of creating somewhat similar conditions in one aspect between the interviewed children in South Africa and Sweden, the schools under study were chosen in areas where there was a shortage of water. During the summer of 2018, inhabitants in several local Swedish communities were asked to limit their use of water, and water restrictions were put in place because of extremely irregular weather patterns. These water restrictions affected people's behaviour. Because the interviews took place in the spring after that dry summer, the memory from the summer lingered on amongst the students. To the questions of whether she had heard about water restrictions, one child responded:

'Yes. Me and my family, we are very much like that. You know, my dad and mum often watch the news and so did I. So, I was fully aware of everything.' (Sweden, school no. 1, student no. 4) [Author's translation]

Some children, like this child, clearly confirmed that they knew very much about water restrictions, whilst others knew less, but overall the children knew of and were aware of restrictions having been put in place. However, two of the children had not heard about them, one of whom had recently migrated to Sweden and the other was hesitant as to having heard about them or not.

The next question about what they had done in their families to save water demonstrated numerous variations in the examples given from the daily lives of families. Not watering the grass or plants using tap water, going for swimming in nearby lakes and the sea instead of taking showers, and taking shorter and fewer showers were amongst the things the children mentioned. Other examples given were by two children who mentioned that instead of letting water run in the tap until it gets cold you can use the refrigerator to cool bottles of water instead. Quite a number of children commented that they could not 'play' and cool themselves off during hot summer days in the way they usually did by running through water sprinklers normally used for watering grass or plants. One child mentioned that in their family they saved rainwater for watering the garden. And in another family, they used water from a nearby dam for the same purpose. A few children told that their families had their own source for water, a well or a dam, and these children demonstrated extra care about water as a limited resource, as did children who lived on farms or who included animals amongst those with whom humans share water. 
In response to the question: why it is important to save water, five Swedish children answered that they did not know or had not thought about why it might be important. Seven children expressed concern that water supplies would not fill up anew if too much was used, implying that water is a limited resource that is important to save. Another group of seven children emphasised that water is needed for the survival of human beings and a few included animals and plants amongst those who depend on water for survival. Finally, one child observed the need for communal water to be there in case of an emergency, like a fire. One of the children commented in her response on the terminology sometimes used when it is said that we could run out of water:

' $[I] \mathrm{t}$ will not run out, but there will be no fresh water left. ... it is strange thinking when someone says we will run out of water. Because, sort of, we live close by the sea [I: Yes] and there is plenty of water there [I: Yes] and if you only sort of clean it, because it is brackish water. [I: But clean water is what is needed] Mmm.' (Sweden, school no. 3, student no. 3) [Author's translation]

According to this girl, the primary limited resource is fresh water for drinking. Summarising the views as expressed by the Swedish children, it is obvious that many of them think it is important to be careful about water because their communities might run out of water, and some of them explicitly connect access to water with the survival of human beings and some additionally include plants and animals amongst those who will not survive without water.

\section{South Africa: Water, a resource at hand?}

When the interviews with the South African children took place, about three quarters of them were living in communities where the water situation was critical and parts of the population were at that time without running water and others were on tight water restrictions. The other quarter of the children had known water restrictions from a year back. In the interviews in the case where communities and the households of the children might be without water, a question of whether they presently had access to running water or not was added. Because the water situation was serious, the children responded to this practical question quite naturally. The household of one of the children did not have water from the tap at the time of the interview and for a few of the others tap water was not regularly available. One child responded to the question of whether her household had water:

\footnotetext{
'Sometimes we do have water coming out of the tap, but my mum says "Every drop counts." Because if there was no water there would be no life. [I: Mmm. So, is there anything special you do to save water?] My mum, every time we buy cold drinks we make sure that we keep the bottle to go and fetch water from the taps.' (South Africa, school no. 3, student no. 1)
}

In this response, the awareness of water as a most limited resource is obvious. The child who said that he did not have water at home at the time of the interview also said that his family had earlier been living on a farm and had water then, but now when they were living in a township no water was there, and his father would bring water from the farm where they had lived (South Africa, school no. 2, student no. 3). All of the children knew about the need to save water. The examples of what to do regarding how to save water were many and varying, like saving rainwater in buckets or tanks, not doing laundry every day, not wasting water when brushing your teeth and not using the tap but using water in buckets when washing the car. Another example of how to save water given by one child was:

'So, my little brother likes water so I take a mug and put it at a half ... [I: Okay] ... and I give him. [I: So you give him just what he is going to drink and not more than that?] Yes. [I: Yeah. Yes, that is a way to save water].' (South Africa, school no. 2, student no. 1)

And the conversation continues:

'Cause, if we don't save water we won't have a chance to have water again. [I: So, we need to save it because otherwise we may not have a chance to have more?] Yes. And, if somebody is not having water for a week he will die. [I: Hmm, that is true. Mm. We really need water to live.] Yeah. [I: Yeah.].' (South Africa, school no. 2, student no. 1)

The answer of this child explicitly connects survival to access to water and when the answers of the South African children are summarised a little more than half of them connect access to water to the survival of human beings, with some also adding plants, animals and the earth, all life, as needing water. The rest of the children speak of the need for water for special purposes like to drink, for health, for how it makes life easier for things such as cooking, and one child also commented that one must be careful about water because it is not free, that it costs money. There were also two students saying that people would have to move from the place where they live if there were no water.

The question of limited water resources was initially put into the interview scheme to create an opening and a similarity between the two countries, but as demonstrated here this led to opening up the serious existential question of access to water. One of the first interviewees succinctly responded in the following way: 'Because without water, because without water you can't live' (South Africa, school no. 1, student no. 1). The reality of human existence that without water we can't live is close to experiences of the interviewed South African children, but is also within reflective reach for more than $1 / 3$ of the Swedish children, and obviously is an existential matter.

\section{Water: An ethical matter}

Looking at water as a resource that is limited and needs to be shared reflects obvious ethical dimensions. One South African girl commented on access to water in the following way:

'... And, if you take a three-minute-shower [I: mm] your neighbour may not have water to also take a shower. [I: Mm].' (South Africa, school no. 4, student no. 2) 
This reflects conscious awareness of how one's agency is related to that of others. Another instance of care is the above given example of a child giving his brother only half a cup of water. Water must not be wasted is the intention seen behind this calculation and this reflects acting responsibly out of concern for one's family and for the good of all. Parents and family members were often mentioned as giving direction as in the following example of how to save water:

'My grandmother said that don't flush the toilet if you only peed. Or if you do a number two then you can flush the toilet, but don't flush the toilet between your pees, or if its low, but if it is brown you can flush it down.' (South Africa, school no. 1 , student no. 3)

Such responsible behaviour when water is restricted was also reported by other children relating to toilet behaviour. The child above continued laconically saying:

'Because if there is no water in the world then no one can live in the world.' (South Africa, school no. 1, student no. 3)

The existential need of human beings for water is here closely connected to the responsible action of saving water in daily life. The word 'tap' is a central word in several responses, thus pointing to the concern for water and the risks of not having access to it.

Although the scarcity of water was not a matter of urgency in the same way to the Swedish children as it was to the South African children, the Swedish children still gave examples of how to save water in daily practices where they assumed responsibility. One child told how his father makes sure that they turn off the taps and care for food properly:

'We were very careful about turning off the taps, sort of, when you are brushing your teeth or something like that. Yes. [I: Mmm] ... One more thing, because it was so warm you could never leave milk or yoghurt on the table. [I: No].' (Sweden, school no. 4 , student no. 1)

As already mentioned, the children also said how instead of letting water run in the tap until it gets cold one can put water in the refrigerator. One thing that cuts through in the stories of Swedish children, and where they as children assumed extra responsibility, was in not cooling themselves off by running through water sprinklers. This is obviously not only a pleasure, a part of play, for Swedish children but also a practical solution when lakes and the sea are not nearby and an opportunity on hot days.

Interesting to note is that this pleasure and other steps and measures taken in the families and where children in both Sweden and South Africa assumed responsibility were not mentioned with regret, but rather were told in a serious tone of necessity for the good of all, for water to be enough, for water to be a common good for all. The children shared insights from their families in confidence, in seriousness and in earnestness.

\section{A 'childist' view and human responsibility Childism according to John Wall}

In Ethics in Light of Childhood, Wall (2010) brought together an encompassing theoretical discussion on childhood based on thorough interdisciplinary studies. Initially, he went through the history of ideas around childhood in philosophy, pedagogy, theology and religion and places this discussion within a contemporary sociological analysis of the conditions of children, and thus lays a foundation for his own development of 'childism' as a contribution to ethical theory (Wall 2010:132). When initially introducing childism, he considered it to be necessary 'in a time of tremendous global change' (Wall 2010:3). Neglect of children will diminish the humanity of all human beings because, he argued, such neglect 'impoverishes the complex webs of social relations in which human beings live and find meaning' (Wall 2010:2). The kind of theoretical selfcritique that is needed he named 'childism', by which he meant 'the effort to respond to the experiences of children by transforming understanding and practices for all' (Wall 2010:3) - the word 'all' being the crucial one.

The first question Wall addressed in this search is what it most basically means to be human from the point of view of childhood (Wall 2010:35-58). Positioning himself in a phenomenological tradition, Wall (2010:39) explored how human being-in-the-world from the point of view of children means to see the connection between human agency and human vulnerability. The meaning of vulnerability is not to be seen as a lack of agency, but rather to understand it as an openness and relationality to the world. If you imagine a new-born child you can see how the child starts a life-long process of passive-active agency with its surroundings, a process that continues throughout all of life. This means that the child, the human being, creatively both engages with and, at the same time, is created by relations, society, culture and history - in passive-active processes of interdependence in relationality where vulnerability and agency are played out.

Next Wall (2010:59-86) addressed what the ethical aim of the human being is in the light of childhood. In encountering the world, the child, the human being, needs to respond, needs to creatively relate to what is happening. To create meaning out of life's situations is a creative process whereby a human being is challenged to incorporate the encounters they are living. Wall considered this meaning-making to take place through narrative processes whereby a person integrates what happens into their own past, present and future. To form an understanding, a narrative of what an encounter means, is at stake. The challenge is to form a new narrative, to interpret and include an experience that might be an expansion from the point of view of a person's earlier experiences. Being a child is then no different from being an adult as all human beings are in a creative life-long process of being challenged through encounters with the world and by relations, and are creating and integrating narratives of the 
past, present and future as this happens. Although the difference is that a child has a limited experience of time and 'relatively fewer past experiences and senses of future possibilities - whilst as one ages it becomes increasingly possible with more experience to interpret time across broader temporal horizons' (Wall 2010:63). Here we see Wall's understanding of human existence as being written into time, as temporal realities. Further on, when Wall elaborated on interconnectedness in human life, he stresses aspects such as the body, relationships and the divine (Wall 2010:74-79).

When Wall elaborated on what we as human beings owe to each other (Wall 2010:87-110), he started by critiquing earlier understandings of human agency where autonomy, individuality and rationality are central. Such understandings of human agency clash with a relational understanding of human existence as briefly laid out here. They additionally bereave children of their possibilities of being understood as exercising moral agency in their own right. This is because children will not be regarded as autonomous, rational and with fully developed individuality, and they will run the risk of being seen as needing care and of being patronised, diminished and marginalised.

Moral obligation according to Wall is about the moral responsiveness to the other. For children and grown-ups, the challenge is the same: to open up in response to what and to whom are 'other' to the self. Children may have fewer experiences of this kind of self-decentring, whilst grown-ups therefore can be seen as having wider responsibilities - but the demand to open up in responsiveness is the same for children, for all humans. Wall concludes: 'Moral life, in sum, is at once self-creative, self-narrative and other-responsive. It demands, as childhood teaches, a growing imagination of humanity' (Wall 2010:110).

\section{Human responsibility and empowered inclusion}

Having sketched above, in the briefest of terms, the theory of John Wall and his understanding of what it means to be human, it is obvious that when Wall discusses human responsibility he sees humanity as one and responsibility as shared. Although there could be situations when adults with their richer experience ought to assume more responsibility, a patronising attitude towards children and youth is never tolerable. When critically reviewing the opportunities of children and youth to express their democratic concerns, Wall (2011) discussed how democratic theory has traditionally excluded children and young people, whilst democratic representation needs to be rethought in order to better cater for differences between human beings. When discussing global justice, Josefsson and Wall (2020) analysed the struggles of children and youth in relation to child labour, migration of children and youth and struggles around climate change and they argue for the need to view these struggles in light of the deep interdependence between human beings. In their discussion where they analyse alternative ways of theorising on the complexities, dependencies and vulnerabilities of marginalised groups, Josefsson and Wall coined the concept of 'empowered inclusion' to provide a resource for further critical discussions. They summarised the need for this by stating that:

[A]s illustrated by child and youth labourers, migrants and climate fighters, global justice involves a recognition of individuals' and groups' deep interdependency, their simultaneous empowerment as agents and disempowerment through historical marginalisation and social vulnerability. (Josefsson \& Wall 2020:1056)

\section{Childist approaches}

In the childist approach as suggested by Wall, it is obvious that the existence of children is seen to point to human existence as being a life-long process where through interdependence and in vulnerability the encounters with the 'other' are a challenge. To make this paradigmatic in the understanding of human existence means viewing children and adults not as binary categories but seeing them as equals in their humanity. This gives an ethical ground for arguing for equal rights in terms of democratic representation for children and young people and awakens a need to rethink present theories of democratic representation. A shared human responsibility between children and adults in relation climate change then further means for the grown-up world to take seriously the concerns of children and young people and to seek ways to act together through empowered inclusion.

Childist or child-centred, perspectives are today additionally raised in various research fields demonstrating tendencies that could potentially affect various practices. For example within South African theology, childist-inspired research has addressed different theological issues such as New Testament studies (Grobbelaar 2020), how to listen to and include the voices of young people when doing theology (Grobbelaar 2019; Johannisen, Yates \& Van Wyk 2019), how to stop the silencing of matters of sexuality by mutual sexual emancipation (Koch, Yates \& Kitching 2019) and studies on necessary epistemological shifts when doing theology with children (De Beer \& Yates 2019). From other disciplinary research contexts, matters such as access to citizenship for young people whose lives have been uprooted through migration are addressed (Josefsson 2019), and in the field of education it has been theoretically explored how children's moral agency in times of the Anthropocene can be understood as a form of moral authorship where children form their own narratives to interpret their lives and how this can be facilitated in education (Sporre, Lotz-Sisitka \& Osbeck forthcoming).

\section{Conclusion}

Through a review of 'childism' as suggested by Wall (2010), the aim of this article has been to point to a theoretical ethical framework whereby it can be recognised how contemporary matters of climate change are given existential and ethical significance by children and young people. In addition, matters of how they are given adequate democratic representation were also touched upon. To sustain the claim 
that these questions are existentially and ethically relevant to children, some results from an interview study with South African and Swedish children were presented that pointed to this being the case. Given the risks that children and young people experience that their concerns are neglected and that they themselves are disregarded and marginalised, a childist approach questions such attitudes by viewing human beingin-the world as one (being equal for children and grownups), and thus that human responsibility is something to be shared. Given, however, the differences between human beings 'empowered integration' can be a crucial concept in seeking to cater to the differences, vulnerabilities and interdependencies between human beings.

\section{Acknowledgements Competing interests}

The author declares that she has no financial or personal relationships that may have inappropriately influenced her in writing this article.

\section{Author's contributions}

K.S. is the sole author of this article.

\section{Ethical considerations}

This project has been approved by three different bodies and appropriate decisions were taken by: (1) Regionala etikprövningsnämnden, Umeå, Sweden. Dnr 2018/325-331. Date of decision: 02 October 2018. (2) The Western Cape Government, Reference: 20180912-6302. Decision signed by the Directorate Research official. (3) Province of the Eastern Cape, Education. 28 January 2019. Decision signed by the Director for strategic planning policy and research.

\section{Funding information}

The author discloses receipt of financial support for the research and authorship from Umeå School of Education, Umeå University, Sweden, and for the publication of this article from the University of the Western Cape, Cape Town, South Africa.

\section{Data availability}

The data that support the findings of this study are kept by the author. The data are not publicly available because of the restrictions.

\section{Disclaimer}

The views and opinions expressed in this article are those of the author and do not necessarily reflect the official policy and position of any affiliated agency of the author.

\section{References}

Braidotti, R., 2013, The post-human, Polity Press, Cambridge.

Cannon, K.G., 1988, Black womanist ethics, Scholars' Press, Atlanta, GA.

Cannon, K.G., 1995, Katie's canon: Womanism and the soul of the black community, Continuum, New York, NY.

Cho, S., Crenshaw, K.W. \& McCall, L., 2013, 'Intersectionality: Theorizing power empowering theory', Signs 38(4), 785-810. https://doi.org/10.1086/669608

Crenshaw, K.W., 1991, 'Mapping the margins', Stanford Law Review 43(6), 1241-1299. https://doi.org/10.2307/1229039

De Beer, S. \& Yates, H., 2019, 'Doing theology with children: Exploring emancipatory methodologies', HTS Teologiese Studies/Theological Studies 75(1), a5840. https:// doi.org/10.4102/hts.v75i1.5840

Fridays for Future, n.d., Activist speeches, viewed 05 March 2021, from https:// fridaysforfuture.org/what-we-do/activist-speeches/.

Frödén, A. \& Quennerstedt, A., 2020, 'The child as a gendered rights holder', Childhood 27(2), 143-157. https://doi.org/10.1177/0907568219886641

Grobbelaar, J., 2019, 'Doing theology with children: Some challenges for adult theologians', HTS Teologiese Studies/Theological Studies 75(1), a5636. https:// doi.org/10.4102/hts.v75i1.5636

Grobbelaar, J., 2020, 'Doing theology with children: A childist reading of the childhood metaphor in 1 Corinthians and the Synoptic Gospels', HTS Teologiese Studies/ Theological Studies 76(4), a5637. https://doi.org/10.4102/hts.v76i4.5637

Hartman, S.G., 1986, Barns tankar om livet [Children's thoughts about life], Natur och Kultur, Stockholm.

Hartman, S.G. \& Torstenson-Ed, T., 2007, Barns tankar om livet [Children's thoughts about life], Natur och kultur, Stockholm.

IPCC, 2021, Climate change 2021. The physical science basis, viewed 16 September 2021, from https://www.ipcc.ch/report/ar6/wg1/downloads/report/IPCC_AR6_ WGI_Full_Report.pdf.

Johannisen, J.C., Yates, H. \& Van Wyk, C., 2019, 'Multidisciplinary meetings: Listening to the experiences of children in a child and youth care centre', HTS Teologiese Studies/Theological Studies 75(1), a5493. https://doi.org/10.4102/hts.v75i1.5493

Josefsson, J., 2019, 'Non-citizen children and the right to stay - a discourse ethical approach', Ethics and Global Politics 12(3), 32-49.

Josefsson, J. \& Wall, J., 2020, 'Empowered inclusion: Theorizing global justice for children and youth', Globalizations 17(6), 1043-1060. https://doi.org/10.1080/14 747731.2020.1736853

Koch, R., Yates, H. \& Kitching, A.E., 2019, 'Adolescent girls' voices on their need for sexuality education: A cry for mutual sexual emancipation', HTS Teologiese
Studies/Theological Studies 75(1), a5495. https://doi.org/10.4102/hts.v75i1.5495

Kvamme, O.A., 2019, 'School strikes, environmental ethical values, and democracy', Pædagogisk Filosofi 8(1), 6-27. https://doi.org/10.7146/spf.v8i1.117967

Sporre, K., Lotz-Sisitka, H. \& Osbeck, C., forthcoming, Taking the moral authorship of children and youth seriously in times of the Anthropocene.

Sundhall, J., 2017, 'A political space for children? The age-order and children's right', Social Inclusion 5(3), 164-171. https://doi.org/10.17645/si.v5i3.969

Wall, J., 2010, Ethics in light of childhood, Georgetown University Press, Washington, DC.

Wall, J., 2011, 'Can democracy represent children? Towards a politics of difference', Childhood 19(1), 86-100. https://doi.org/10.1177/0907568211406756

Wall, J., 2019, 'Theorizing children's global citizenship: Reconstructionism and the politics of deep interdependence', Global Studies of Childhood 9(1), 5-7. https:// doi.org/10.1177/2043610618815484

Young, I.M., 1990, Justice and the politics of difference, Princeton University Press, Princeton, NJ.

Young, I.M., 1997, Intersecting voices: Dilemmas of gender, political philosophy, and policy, Princeton University Press, Princeton, NJ. 